\title{
Paratesticular Leiomyoma
}

National Cancer Institute

\section{Source}

National Cancer Institute. Paratesticular Leiomyoma. NCI Thesaurus. Code C162494.

A leiomyoma that arises from the paratesticular region. 